\title{
Percutaneous access for the diagnosis of urothelial neoplasms: pictorial essay with anatomopathological correlation
}

\author{
Acesso percutâneo no diagnóstico de neoplasias uroteliais: ensaio iconográfico com correlação \\ anatomopatológica
}

\section{Thiago Franchi Nunes ${ }^{1, a}$, Tiago Kojun Tibana ${ }^{1, b}$, Rômulo Florêncio Tristão Santos ${ }^{1, \mathrm{c}}$, Bernardo Bacelar de Faria ${ }^{2, \mathrm{~d}}$, Vinicius Adami Vayego Fornazari ${ }^{3, e}$, Edson Marchiori ${ }^{4, f}$}

1. Hospital Universitário Maria Aparecida Pedrossian da Universidade Federal de Mato Grosso do Sul (HUMAP-UFMS), Campo Grande, MS, Brazil. 2. Laboratório Scapulatempo, Campo Grande, MS, Brazil. 3. Escola Paulista de Medicina da Universidade Federal de São Paulo (EPMUnifesp), São Paulo, SP, Brazil. 4. Universidade Federal do Rio de Janeiro (UFRJ), Rio de Janeiro, RJ, Brazil.

Correspondence: Dr. Thiago Franchi Nunes. Avenida Senador Filinto Müller, 355, Vila Ipiranga. Campo Grande, MS, Brazil, 79080-190. Email: thiagofranchinunes@gmail.com.

a. https://orcid.org/0000-0003-0006-3725; b. https://orcid.org/0000-0001-5930-1383; c. https://orcid.org/0000-0002-8679-7369; d. https://orcid.org/0000-0002-4258-2198; e. https://orcid.org/0000-0002-5880-1703; f. https://orcid.org/0000-0001-8797-7380.

Received 19 July 2019. Accepted after revision 8 October 2019.

How to cite this article:

Nunes TF, Tibana TK, Santos RFT, Faria BB, Fornazari VAV, Marchiori E. Percutaneous access for the diagnosis of urothelial neoplasms: pictorial essay with anatomopathological correlation. Radiol Bras. 2020 Set/Out;53(5):345-348.

Abstract Urothelial carcinoma is a rare malignant neoplasm, accounting for only $5 \%$ to $7 \%$ of kidney tumors and $5 \%$ of urothelial tumors. During the management of urothelial carcinoma, anatomopathological evaluation is used for stratifying the tumors into different prognostic groups to aid in the evaluation of treatment results and to optimize the management of patients. Percutaneous image-guided biopsy is a safe and feasible procedure, with high sensitivity and accuracy rates. Although image-guided percutaneous biopsy of the urinary tract is a relatively uncommon procedure, it can be considered an option in selected cases or when traditional methods, such as the ureteroscopic technique, are not possible.

Keywords: Percutaneous access; Urinary tract; Malignancy.

Resu mo o carcinoma urotelial é uma neoplasia maligna rara, responsável por apenas 5\% a 7\% dos tumores renais e 5\% dos tumores uroteliais. No manejo do carcinoma urotelial, a determinação anatomopatológica tem por objetivo estratificar os tumores em diferentes grupos prognósticos, para permitir avaliar resultados do tratamento e otimizar o gerenciamento dos pacientes. Biópsia percutânea guiada por imagem é um procedimento seguro e tecnicamente viável, com alta sensibilidade e taxa de precisão. Apesar de as biópsias percutâneas guiadas por imagem do trato urinário serem um procedimento relativamente incomum, podem ser consideradas como opção em casos selecionados ou quando os métodos tradicionais, como o a técnica ureteroscópica, não são possíveis.

Unitermos: Acesso percutâneo; Trato urinário; Malignidade.

\section{INTRODUCTION}

Urothelial carcinoma is a rare malignant neoplasm, accounting for only 5\% to $7 \%$ of kidney tumors and 5\% of urothelial tumors. Although radical surgery is the gold standard treatment for patients with urothelial carcinoma, endoscopic advances have resulted in favorable outcomes after treatment and renal preservation in selected cases, even in patients with a normal contralateral kidney ${ }^{(1,2)}$. As the careful selection of patients for treatment is crucial, obtaining a satisfactory sample for diagnosis is an essential step in determining the treatment and prognosis of patients with urothelial carcinoma ${ }^{(3)}$.

Biopsy is an integral component for the evaluation of potentially malignant lesions of the ureter and other malignancies of the upper urinary tract. When indicated, biopsy is usually performed via ureteroscopy. However, ureteroscopic biopsy may not be possible in patients with highrisk comorbidities, as it is invasive and requires general anesthesia and the insertion of ureteral catheters. Thus, although ureteroscopy remains the gold standard, it can be technically challenging and is associated with significant rates of false-negative results, depending on the morphological characteristics of the lesion ${ }^{(4)}$. Several imageguided interventional techniques have been evaluated in Brazilian radiology studies ${ }^{(5-9)}$.

Percutaneous biopsy can be performed in selected cases when the target segment of the ureter or renal pelvis cannot be accessed via ureteroscopy, is predominantly exophytic and non-endoluminal, or showed inconclusive results in previous samples.

\section{ULTRASOUND-GUIDED BIOPSY (TRANSABDOMINAL AND ENDOCAVITARY)}

Ultrasound appears to have several advantages as a guidance method. It is commonly available and does not involve ionizing radiation, and the device is portable and 
provides images in real time (Figure 1). Unfortunately, not all small kidney tumors can be visualized on ultrasound, and adjacent structures and organs may not be differentiated properly, unlike that observed using computed tomography (CT). Furthermore, gaseous and bony structures may impair visualization ${ }^{(10)}$. However, the needle can be directed towards solid components in the mass, and the location can be confirmed at the time of the biopsy, thereby obtaining a more precise positioning of the needle and a better fragment of the lesion ${ }^{(10)}$.

\section{CT-GUIDED BIOPSY}

CT-guided percutaneous biopsy of ureteral lesions and collecting system is a useful alternative to obtain samples of suspicious lesions in challenging clinical situations
(Figure 2). Common clinical scenarios appropriate for a CT-guided percutaneous approach include cases of ileal urinary ducts, unfavorable anatomy, inability to perform ureteroscopic access, inability to perform the ultrasoundguided procedure, or unsuccessful ureteroscopic biopsy in cases with high clinical suspicion of malignancy ${ }^{(11)}$.

\section{FLUOROSCOPY-GUIDED FORCEPS BIOPSY}

Forceps are very effective for obtaining tissues of malignant biliary stenoses ${ }^{(12,13)}$. The tool is composed of a sheath and forceps, which are advanced alongside a 0.035 guidewire as needed. This technique allows performing biopsy of the stenosis through the sheath, leaving a 0.035 thread to preserve access to the lesion (Figure 3). This is also advantageous when the distal wire needs to be

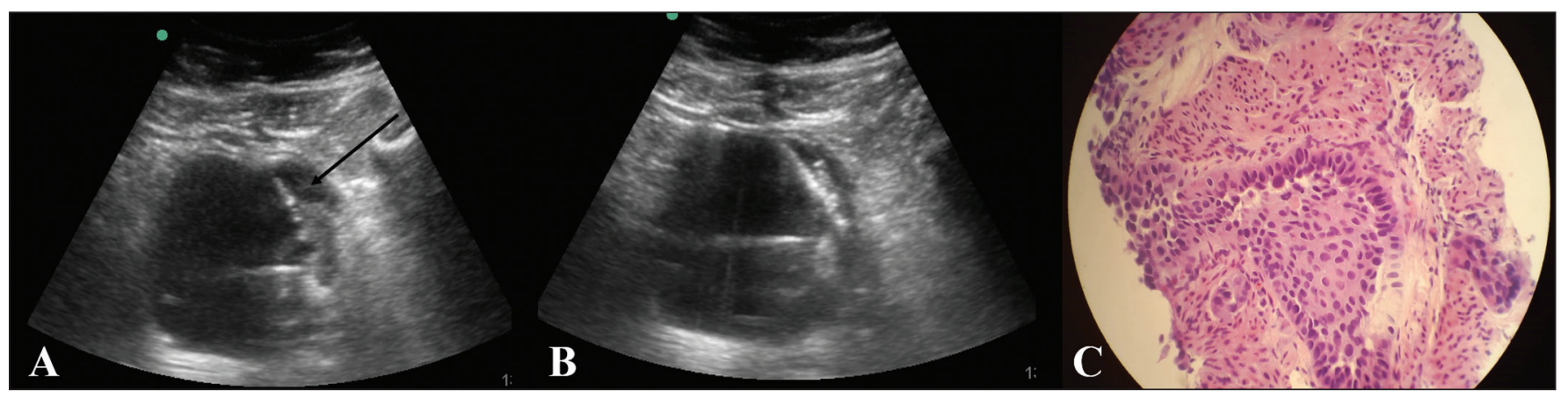

Figure 1. A: Ultrasound of the bladder showing a 17-G $\times 13-\mathrm{cm}$ coaxial needle (arrow) positioned adjacent to the vegetating lesion on the left-side wall of the bladder. B: Percutaneous biopsy using an $18-\mathrm{G} \times 16-\mathrm{cm}$ tru-cut needle. C: Anatomopathological examination revealed invasive urothelial carcinoma.

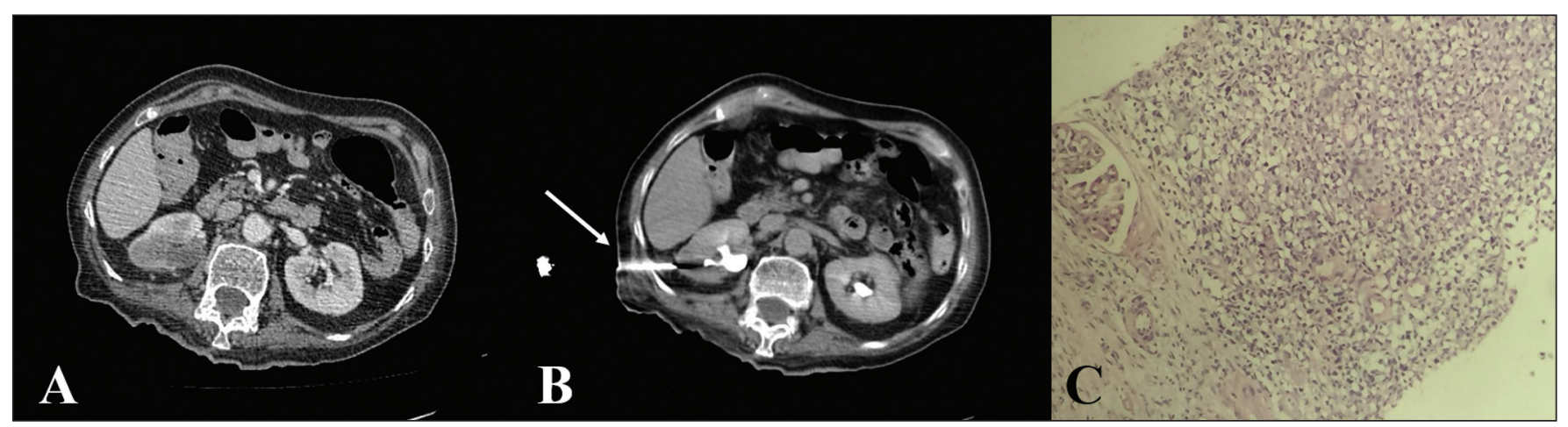

Figure 2. A: CT scan of the abdomen, axial section, showing an ill-defined urothelial lesion in the middle third of the right kidney. B: Performance of the CT-guided biopsy (arrow) using the coaxial technique after injection of the contrast agent in the excretory phase. C: Anatomopathological examination revealed invasive urothelial carcinoma.

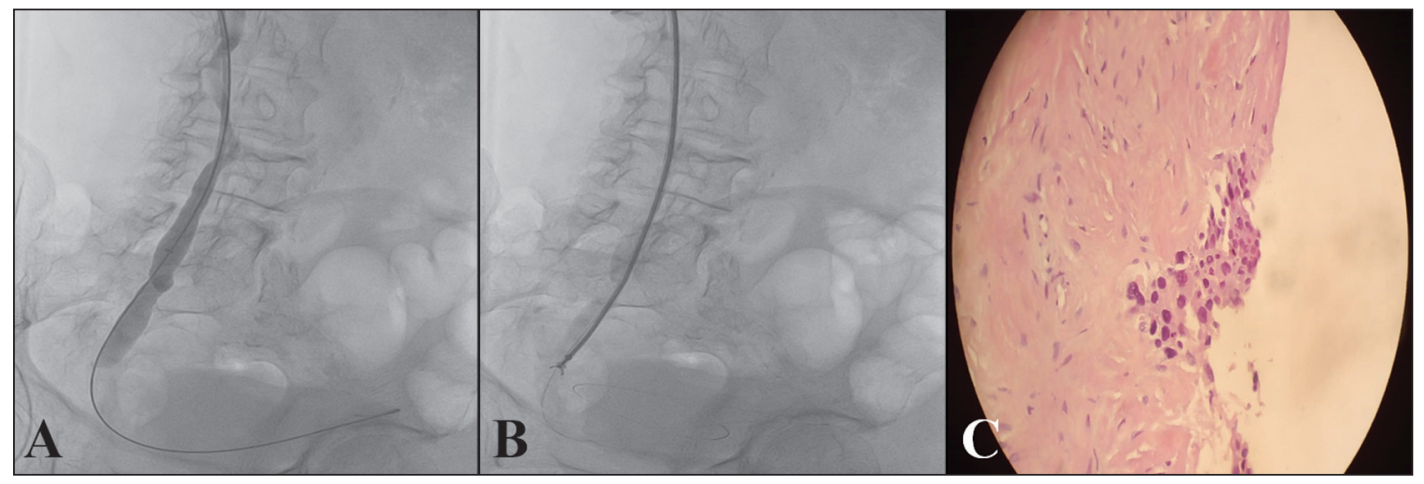

Figure 3. A: Urethrography showing an obstructive lesion in the right distal ureter and crossing of the obstructive site using a hydrophilic guidewire up to the bladder. B: A 7-F $\times 45-\mathrm{cm}$ sheath positioned up to the region close to the obstructive site, and performance of forceps biopsy. C: Pathological examination revealed well-differentiated urothelial neoplasia. 
correctly positioned for subsequent procedures. Despite its reported success, very few studies have addressed the use of forceps and its techniques to obtain samples from non-biliary regions ${ }^{(14)}$. Moreover, the use of forceps is a relatively safe and effective technique that makes histology-guided oncological treatment possible ${ }^{(15)}$.

\section{BIOPSY WITH ASSOCIATED TECHNIQUES}

Current imaging modalities allow performing biopsies of focal lesions in several deep abdominal and pelvic organs, thereby helping in obtaining a safe and effective diagnosis $^{(16,17)}$. In situations where bladder tumors are not easily accessed via biopsy or cystoscopy, alternative methods for the acquisition of tissue samples, such as CT, ultrasound, or fluoroscopy, can be used alone or together to perform a percutaneous biopsy (Figures 4 and 5).

\section{CONCLUSION}

Image-guided percutaneous biopsy of the upper urinary tract collecting system appears to be a safe and ef-

Figure 4. A: Pyelography performed before percutaneous insertion of the double J catheter showing stenosis of the proximal ureter with parietal irregularities (arrow). B: Post-contrast coronal abdominal CT scan, MIP reconstruction, showing the properly positioned double J catheter. C: CT-guided percutaneous biopsy with posterior access and coaxial technique showing ureter thickening with maintenance of the double J catheter for ureteral protection. Anatomical and pathological examination revealed an inflammatory pseudotumor of the ureter.
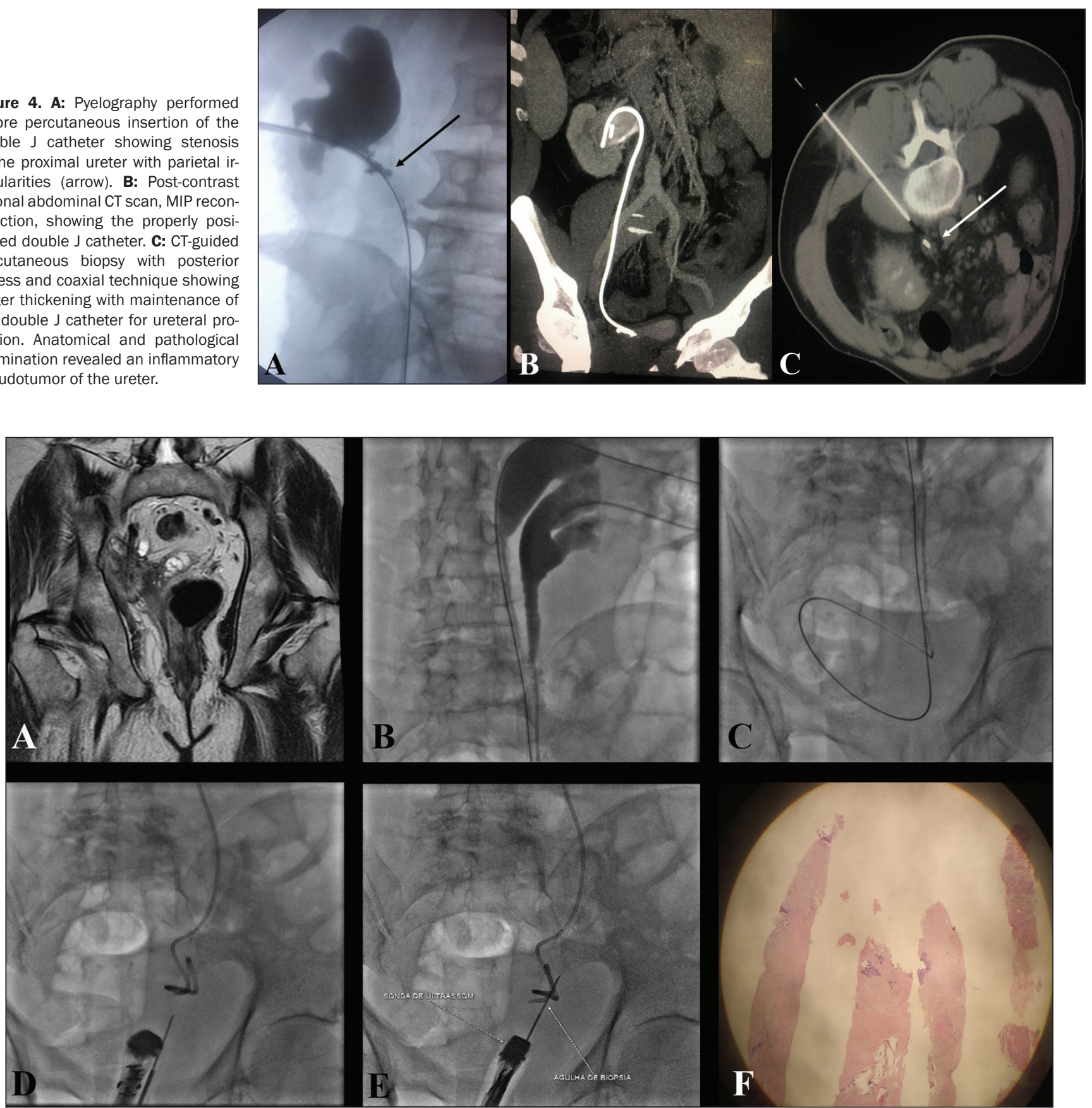

Figure 5. A: T1-weighted magnetic resonance imaging of the pelvis showing marked hydronephrosis of the right kidney, along with an extraperitoneal pelvic lesion in the distal ureter and signs of invasion of the bladder, seminal vesicle, and prostate. B: With the patient in the supine position, pyelography was performed before the procedure that confirmed complete ureteral duplication. C: Percutaneous insertion of a double J catheter (upper cup) and nephrostomy (lower cup). D,E: Endorectal ultrasound and fluoroscopy-guided percutaneous biopsy. F: Anatomopathological report revealed poorly differentiated urothelial neoplasia. 
fective alternative in selected patients who underwent unsuccessful ureteroscopy or who are inadequate candidates for this procedure. In selected patients who do not have a double J catheter, insertion can be performed using the percutaneous technique ${ }^{(18)}$ before biopsy.

\section{REFERENCES}

1. Chen GL, Bagley DH. Ureteroscopic management of upper tract transitional cell carcinoma in patients with normal contralateral kidneys. J Urol. 2000;164:1173-6.

2. Elliott DS, Segura JW, Lightner D, et al. Is nephroureterectomy necessary in all cases of upper tract transitional cell carcinoma? Long-term results of conservative endourologic management of upper tract transitional cell carcinoma in individuals with a normal contralateral kidney. Urology. 2001;58:174-8.

3. Kleinmann N, Healy KA, Hubosky SG, et al. Ureteroscopic biopsy of upper tract urothelial carcinoma: comparison of basket and forceps. J Endourol. 2013;27:1450-4.

4. Vashistha V, Shabsigh A, Zynger DL. Utility and diagnostic accuracy of ureteroscopic biopsy in upper tract urothelial carcinoma. Arch Pathol Lab Med. 2013;137:400-7.

5. Schiavon LHO, Tyng CJ, Travesso DJ, et al. Computed tomographyguided percutaneous biopsy of abdominal lesions: indications, techniques, results, and complications. Radiol Bras. 2018;51:141-6.

6. Falsarella PM, Rocha RD, Rahal Junior A, et al. Minimally invasive treatment of complex collections: safety and efficacy of recombinant tissue plasminogen activator as an adjuvant to percutaneous drainage. Radiol Bras. 2018;51:231-5.

7. Tibana TK, Grubert RM, Silva CMDR, et al. Percutaneous cholangioscopy for the treatment of choledocholithiasis. Radiol Bras. 2019;52:314-5.

8. Tibana TK, Grubert RM, Santos RFT, et al. Percutaneous nephros- tomy versus antegrade double-J stent placement in the treatment of malignant obstructive uropathy: a cost-effectiveness analysis from the perspective of the Brazilian public health care system. Radiol Bras. 2019;52:305-11.

9. Tibana TK, Fornazari VAV, Gutierrez Junior W, et al. What the radiologist should know about the role of interventional radiology in urology. Radiol Bras. 2019;52:331-6.

10. Lee SW, Lee MH, Yang HJ, et al. Experience ofultrasonographyguidedpercutaneous core biopsy for renal masses. Korean J Urol. 2013;54:660-5.

11. Hendrickson AC, Schmitz JJ, Kurup AN, et al. Percutaneous ureteral biopsy: safety and diagnostic yield. Abdom Radiol (NY). 2019; 44:333-6.

12. Inchingolo R, Spiliopoulos S, Nestola M, et al. Outcomes of percutaneous transluminal biopsy of biliary lesions using a dedicated forceps system. Acta Radiol. 2019;60:602-7.

13. Park JG, Jung GS, Yun JH, et al. Percutaneous transluminal forceps biopsy in patients suspected of having malignant biliary obstruction: factors influencing the outcomes of 271 patients. Eur Radiol. 2017;27:4291-7.

14. Carr CS, Rawlins R, Brown KM, et al. Intraluminal biopsy of a superior vena cava mass. Eur J Cardiothorac Surg. 2001;19:724-5.

15. Thomson B, Kawa B, Rabone A, et al. Fluoroscopic guided transluminal biopsy of the oesophagus and ureter with a biliary biopsy forceps kit. Cardiovasc Intervent Radiol. 2019;42:1045-7.

16. Gupta S, Madoff DC, Ahrar K, et al. CT-guided needle biopsy of deep pelvic lesions by extraperitoneal approach through iliopsoas muscle. Cardiovasc Intervent Radiol. 2003;26:534-8.

17. Gupta S, Nguyen HL, Morello FA Jr, et al. Various approaches for CT-guided percutaneous biopsy of deep pelvic lesions: anatomic and technical considerations. Radiographics. 2004;24:175-89.

18. Nunes TF, Tibana TK, Santos RFT, et al. Percutaneous insertion of bilateral double J stent. Radiol Bras. 2019;52:104-5. 